\title{
THE DETERMINATION OF THE MAIN FACTORS AFFECTING THE CHOICE OF CHILDREN'S CLOTHES BY THE PARENIS AND DURATION OF THE USE OF EVERY LAYER OF CLOTHES FOR A DAY
}

\author{
Platonova A.H., Yatskovska N.Y., Shkarban K.S., Saienko H.M.
}

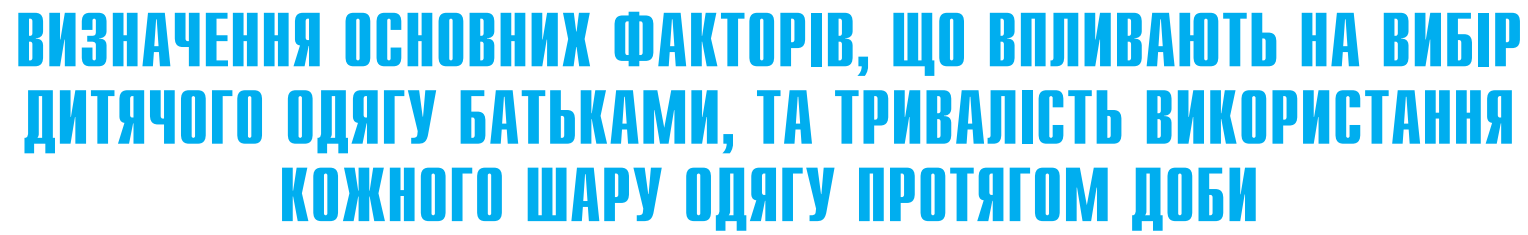

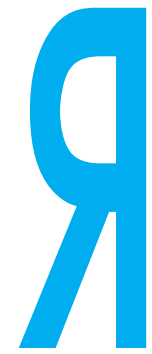

ПЛАТОНОВА А.Г., ЯЦКОВСЬКА Н.Я.,

ШКАРБАН К.С., САЄНКО Г.М.

ДУ «Інститут громадського

здоров'я ім. О.М. Марзєєва

НАМН України», м. Київ

Удк $613.95: 613.48$

Ключові слова: дитячий одяг, пріоритети батьків, тривалість використання протягом доби, діти різного віку. к відомо, одяг забезпечує захист поверхні шкіри людини від механічного пошкодження, забруднення та несприятливого впливу зовнішнього середовища. За допомогою одягу навколо тіла створюється штучний мікроклімат, який суттєво впливає на процеси теплообміну між організмом та довкіллям, полегшує терморегуляторну функцію шкіри, забезпечує процеси газообміну через шкірні покрови.

Захисні властивості одягу особливо важливі для дітей, бо у дитячому віці механізми терморегуляції дуже недосконалі, переохолодження та перегрівання організму можуть призвести до порушень стану здоров'я. Діти відрізняються великою руховою активністю, за якої рівень теплопродукції зростає у 2-4 рази. Шкіра дітей ніжна і вразлива, дихання через шкіру має більшу питому вагу в обмінних процесах організму, ніж у дорослих. Тому дитячий одяг за своєю конструкцією і фізико-гігієнічними показниками матеріалів має відповідати віковим анатомо-фізіологічним особливостям, виду діяльності і метеорологічним умовам, не перешкоджати швидкому і легкому надяганню і зняттю, сприяти вихованню естетичного смаку дитини.

Нині понад 50\% різних видів одягу, у т.ч. дитячого, виготовляються із синтетичних тканин або з домішками синтетичних волокон, що викликає певне занепокоєння фахівців профілактичного напрямку медицини [1, 2]. Сучасні технології дозволяють створити тканини і трикотажні полотна з високо-
ОПРЕДЕЛЕНИЕ ОСНОВНЫХ ФАКТОРОВ, ВЛИЯЮЩИХ НА ВЫБОР ДЕТСКОЙ ОДЕЖДЫ РОДИТЕЛЯМИ, И ДЛИТЕЛЬНОСТЬ ИСПОЛЬЗОВАНИЯ КАЖДОГО СЛОЯ ОДЕЖДЫ НА ПРОТЯЖЕНИИ СУТОК

Платонова А.Г., Яцковская Н.Я., Шкарбан Е.С., Саенко Г.М.

ГУ «Институт общественного здоровья им. А.Н. Марзеева НАМН Украины», Г. Киев

Актуальность. Появление качественно новых тканей и увеличивающийся ассортимент детской одежды нуждаются в усовершенствовании методических подходов и расширении перечня показателей, применяющихся для гигиенической оценки текстильных изделий. В решении широкого спектра заданий, связанных с формированием комплекса показателей для гигиенической оценки непродовольственных товаров, важную роль играют исследование свойств самого товара и приобретение объективной информации от потребителя относительно его виденья наиболее весомых вопросов, связанных с выбором и использованием товаров для детей.

Цель. Установить основные факторы, влияющие на выбор родителями детской одежды разного функционального назначения и длительность использования каждого слоя одежды детьми на протяжении суток.

Материалы и методы. Проведено анкетирование родителей 180 детей в возрасте от 1 года до 17 лет. Анализ результатов анкетирования проводили с учетом возрастной периодизации развития детей. Результаты были обработаны в электронных таблицах Ехсеl с помощью методик вариационной статистики.

Результаты. Проведенное анкетирование свидетельствует о том, что более двух третей опрошенных родителей покупают детскую одежду более 4 раз в год. Подавляющее большинство родителей покупает одежду в гипермаркетах и магазинах, где есть специализированные отделы. В то же время 41,67\% семей покупают одежду в Интернет-магазинах, 45,00\% - у частных лиц на рынке. Более двух третей родителей отдают предпочтение отечественным производителям детской одежды. Подавляющее большинство опрошенных имеет негативное отношение к наличию синтетических волокон в составе тканей для детской одежды первого слоя. Ведущими факторами, влияющими на выбор одежды при ее покупке, родители отметили ее качество, внешний вид, безопасность для здоровья, состав ткани и цену. Средняя длительность ношения одежды первого слоя составляет от 7,22 до 10,45 часов в сутки. При этом длительность ношения одежды первого слоя детьми всех возрастных групп достоверно выше (в среднем в 1,5 раза) сравнительно с длительностью ношения одежды второго слоя (в среднем в 2,7 раза) и длительностью ношения одежды третьего слоя.

Ключевые слова: детская одежда, приоритеты родителей, продолжительность использования в течение суток, дети разного возраста.

() Платонова А.Г., Яцковська Н.Я., Шкарбан К.С., Саєнко Г.М. СТАТТЯ, 2017. 
тривкої хімічної сировини зі стійкими показниками, що мають широкий діапазон фізико-хімічних та фізико-механічних властивостей [3]. Разом 3 цими позитивними властивостями тканини із синтетичних волокон мають деякі негативні якості. Передусім це стосується здатності тканин із полімерних матеріалів створювати електричне поле високої напруги. Низькі сорбційні та ліпофільні властивості зумовлюють здатність таких тканин утримувати запахи й вологу. У повітря простору під одягом при експлуатації можуть мігрувати незаполімеризовані мономери, компоненти допоміжних речовин та інші сполуки. Такі речовини у разі інгаляційного надходження, резорбції через шкіру можуть бути причиною негативного біологічного впливу на організм людини.

3 метою попередження несприятливого впливу на здо-

Розподіл респондентів за відповіддю на питання щодо переваг відносно місця купівлі дитячого одягу, \%

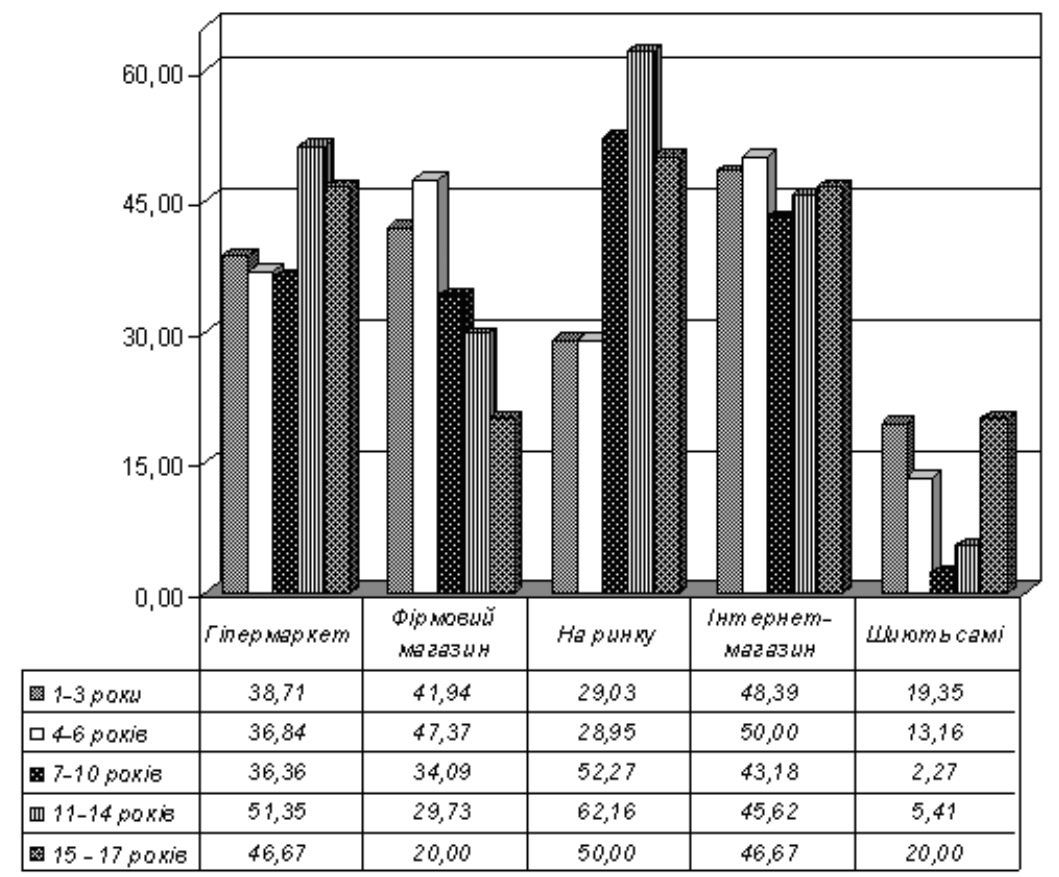
застосовуються для гігієнічної оцінки текстильних виробів.

у вирішенні широкого спектра завдань, пов'язаних з формуванням комплексу показників для гігієнічної оцінки непродовольчих товарів, важливу роль відіграють дослідження властивостей самого товару та набуття об'єктивної інформації від споживача щодо його бачення найбільш вагомих питань, пов'язаних з вибором та експлуатацією товарів для дітей.

Метою роботи було встановити основні фактори, що впливають на вибір батьків при купівлі дитячого одягу різного функціонального призначення, та тривалість використання кожного шару одягу дітьми протягом доби.

Матеріали та методи. Зважаючи на те, що особами, які приймають рішення щодо купівлі одягу, найчастіше $€$ батьки дитини, то для досяг-

Рисунок ров'я людини факторів, пов'язаних з виробництвом та появою на ринку України продукції, що несе потенційну небезпеку для здоров'я дітей, було введено санітарно-епідеміологічну оцінку товарів дитячого асортименту [4].

Тим не менш, поява якісно нових тканин та розширення асортименту дитячого одягу потребують удосконалення методичних підходів і розширення переліку показників, що

.

\section{0} товарів $(41,94 \%$ і $47,37 \%)$ та Інтернет-магазинах $(48,39 \%$ i 50,00\%). Батьки дітей цього віку вірогідно рідше користуються послугами приватних продавців на ринку $(\leq 0,05)$. Починаючи з вікової групи 7-10 років основним місцем купівлі дитячого одягу стають ринки. Там купують товари 52,27\% батьків дітей зазначеного віку, 62,16\% батьків дітей 11-14 та $50,00 \%$ батьків дітей 15-17 років (рис.).

Українські родини віддають перевагу товарам, які пропонують вітчизняні виробники (50,00-83,78\%), виробники країн ЄC $(26,32-59,09 \%)$ та Туреччини $(35,48-55,26 \%)$. Відсоток батьків, що мають дітей віком 11-14 та 15-17 років, купують одяг, імпортова- 
THE DETERMINATION OF THE MAIN FACTORS AFFECTING THE CHOICE OF CHILDREN'S CLOTHES BY THE PARENTS AND DURATION OF THE USE OF EVERY LAYER OF CLOTHES FOR A DAY

Platonova A.H., Yatskovska N.Y., Shkarban K.S., Saienko H.M.

SI "O. M. Marzeiev Institute for Public Health of the National Academy of Medical Sciences of Ukraine", Kyiv

Background. The emergence of the new fabrics and widening of the assortment of children's clothes needs the improvement of the methodological approaches and widening of the list of the indicators using for the hygienic assessment of textile products. Both the investigations of the qualities of goods and obtaining of the objective information from the customers about the most significant issues regarding the choice and exploitation of children's goods play an important role in the solution of the wide spectrum of the tasks connected with the formation of the complex of the indicators for hygienic assessment of nonfood items.

Objective. We determined the main factors affecting a choice of the parents of the children's clothes of different functional purposes and the duration of the use of every layer of children's clothes throughout the day. Materials and methods. We performed the questionnaire survey of the parents of 180 children aged 1-17 years old. The analysis of the results was carried out taking into account the age periodization of children's development. The results were calculated in Excel electronic tables with the help of the methods of variation statistics.

Results. Performed questionnaire survey shows that over two- third of interviewed parents buy the children's clothes more than 4 times a year. The majority of the parents buy clothes in the hypermarkets and the stores with specialized departments. At the same time $41.67 \%$ of the families buy clothes in the Internetshops and $45.00 \%$ of the children wear clothes bought from private persons at the market. More than twothird of parents prefer domestic manufacturer of children's clothes. The majority of the respondents regard the synthetic fibers in the first layer of children's clothes negatively. The main factors affecting the choice of the parents, when buying clothes, were quality, outward, safety for health, fabric structure and price. The average duration of the wearing of the first layer of clothes makes up 7.22-10.45 hours in a day. And duration of the wearing of the first layer of clothes by the children is authentically longer in comparison with the duration of wearing of the second layer of clothes (on the average by 1.5 fold) and in comparison with duration of wearing of the third layer of clothes (on the average by 2.7 fold). Keywords: children's clothes, parents' priorities, using duration for a day, children of different ages.

Таблиця 1

Розподіл респондентів за відповіддю на запитання щодо факторів, які впливають на їхній вибір при купівлі дитячого одягу, \%

\begin{tabular}{|c|c|c|c|c|c|}
\hline \multirow{2}{*}{$\begin{array}{l}\text { Фактори, що впливають } \\
\text { на вибір дитячого одягу }\end{array}$} & \multicolumn{5}{|c|}{ Вікова група дітей } \\
\hline & $\begin{array}{c}1-3 \text { роки, } \\
n=31\end{array}$ & $\begin{array}{c}\text { 4-6 років, } \\
n=38\end{array}$ & $\begin{array}{c}\text { 7-10 років, } \\
\mathrm{n}=44\end{array}$ & $\begin{array}{c}\text { 11-14 років, } \\
n=37\end{array}$ & $\begin{array}{c}\text { 15-17 років, } \\
n=30\end{array}$ \\
\hline Зовнішній вигляд моделі & $\begin{array}{c}61,29 \pm 8,75 \\
\star 2,4,5,6 \# 2,3,4,5\end{array}$ & $\begin{array}{c}97,37 \pm 2,60 \\
\star 2,3,5,6,8 \# 1\end{array}$ & $\begin{array}{c}86,36 \pm 5,17 \\
\star 2,4,5,6,8 \# 1\end{array}$ & $\begin{array}{l}94,60 \pm 3,72 \\
\star 2,5,6,8 \# 1\end{array}$ & $\begin{array}{c}93,33 \pm 4,56 \\
\star 2,3,5,7,8 \# 1\end{array}$ \\
\hline $\begin{array}{l}\text { Популярність } \\
\text { торговельної марки }\end{array}$ & $\begin{array}{c}9,68 \pm 5,31 \\
* 1,3,4,5,7,8 \# 5\end{array}$ & $\begin{array}{r}15,79 \pm 5,92 \\
* 1,3,4,6,7,8\end{array}$ & $\begin{array}{c}13,64 \pm 5,17 \\
* 1,3,4,5,6,7,8\end{array}$ & $\begin{array}{r}18,92 \pm 6,44 \\
\star 1,3,4,6,7,8\end{array}$ & $\begin{array}{c}33,34 \pm 8,61 \\
* 1,4,6,7,8 \# 1\end{array}$ \\
\hline Склад тканини & $\begin{array}{l}74,19 \pm 7,86 \\
* 2,5,6 \# 5\end{array}$ & $\begin{array}{c}76,31 \pm 6,90 \\
* 1,2,4,5,6,8 \text { \#5 }\end{array}$ & $\begin{array}{l}77,27 \pm 6,32 \\
\star 2,4,5,6 \# 5\end{array}$ & $\begin{array}{l}86,49 \pm 5,62 \\
\star 2,5,8 \# 5\end{array}$ & $\begin{array}{c}50,00 \pm 9,13 \\
* 1,4,6 \# 1,2,3,4\end{array}$ \\
\hline Якість & $\begin{array}{c}100,00 \pm 11,02 \\
* 1,2,5,6,8\end{array}$ & $\begin{array}{c}94,74 \pm 3,62 \\
\star 2,3,5,6,8\end{array}$ & $\begin{array}{l}97,73 \pm 2,25 \\
* 1,3,5,6,7,8\end{array}$ & $\begin{array}{c}89,19 \pm 5,10 \\
\star 2,3,5,6,8\end{array}$ & $\begin{array}{c}96,66 \pm 3,26 \\
\star 2,3,5,7,8\end{array}$ \\
\hline $\begin{array}{l}\text { Країна-виробник (вітчиз- } \\
\text { няний або імпортний) }\end{array}$ & $\begin{array}{l}32,26 \pm 8,40 \\
* 1,2,3,4,7,8\end{array}$ & $\begin{array}{l}21,05 \pm 6,61 \\
* 1,3,4,6,7,8\end{array}$ & $\begin{array}{c}31,82 \pm 7,02 \\
* 1,3,4,7,8\end{array}$ & $\begin{array}{l}21,62 \pm 6,77 \\
* 1,4,6,7,8\end{array}$ & $\begin{array}{c}33,33 \pm 8,61 \\
* 1,4,6,7,8\end{array}$ \\
\hline Уподобання дитини & $\begin{array}{c}29,03 \pm 8,15 \\
* 1,3,4,7,8 \# 3,4,5\end{array}$ & $\begin{array}{c}47,37 \pm 8,10 \\
* 1,2,3,4,5,7 \# 5\end{array}$ & $\begin{array}{l}52,27 \pm 7,53 \\
* 1,3,4 \# 1,5\end{array}$ & $\begin{array}{c}67,57 \pm 7,69 \\
* 1,2,4,5 \# 1,5\end{array}$ & $\begin{array}{c}96,67 \pm 3,26 \\
\star 2,3,5 \# 1,2,3,4\end{array}$ \\
\hline $\begin{array}{l}\text { Безпека для здоров'я } \\
\text { дитини }\end{array}$ & $\begin{array}{l}80,65 \pm 7,10 \\
\quad * 2,5,6\end{array}$ & $\begin{array}{l}86,85 \pm 5,48 \\
\star 2,5,6,8 \# 5\end{array}$ & $\begin{array}{c}81,80 \pm 5,82 \\
* 2,4,5,8\end{array}$ & $\begin{array}{l}89,19 \pm 5,10 \\
* 2,5,8 \# 5\end{array}$ & $\begin{array}{c}63,33 \pm 8,80 \\
* 1,2,4,5,6,8 \# 2,4\end{array}$ \\
\hline Ціна & $\begin{array}{l}67,74 \pm 8,40 \\
\star 2,4,5,6\end{array}$ & $\begin{array}{l}44,74 \pm 8,07 \\
\star 1,2,3,4,5,7\end{array}$ & $\begin{array}{c}59,09 \pm 7,41 \\
\star 1,4,5,7\end{array}$ & $\begin{array}{l}62,16 \pm 7,97 \\
\star 1,2,3,4,5,7\end{array}$ & $\begin{array}{c}60,00 \pm 8,94 \\
\star 1,2,4,5,7\end{array}$ \\
\hline
\end{tabular}

\section{Примітки:}

*1 - відмінності вірогідні порівняно з покупцями, на вибір яких впливає зовнішній вигляд моделі $(\leq 0,05) ;{ }^{\star 2}-$ відмінності вірогідні порівняно з покупцями, на вибір яких впливає популярність торговельної марки дитячого одягу $(\leq 0,05)$; *3 - відмінності вірогідні порівняно з покупцями, на вибір яких впливає склад тканини дитячого одягу $(\leq 0,05) ;{ }^{*} 4$ - відмінності вірогідні порівняно з покупцями, які віддають перевагу якісному дитячому одягу $(\leq 0,05) ;$ *5 _ відмінності вірогідні порівняно з покупцями, на вибір яких впливає виробник (вітчизняний або імпортний) дитячого одягу $(\leq 0,05)$; *6 - відмінності вірогідні порівняно з покупцями дитячого одягу, на вибір яких впливає уподобання дитини (<0,05); *7 - відмінності вірогідні порівняно 3 покупцями дитячого одягу, на вибір яких впливає безпека його для здоров'я дитини $(\leq 0,05)$; *8 - відмінності вірогідні порівняно з покупцями, на вибір яких впливає ціна дитячого одягу $(\leq 0,05) ; \#^{1}$ - відмінності вірогідні порівняно 3 респондентами, що купують одяг для дітей віком від 1 до 3 років $(\leq 0,05) ; \#^{2}-$ відмінності вірогідні порівняно з респондентами, що купують одяг для дітей віком від 4 до 6 років $(\leq 0,05) ; \#^{3}$ - відмінності вірогідні порівняно з респондентами, що купують одяг для дітей віком від 7 до 10 років $(\leq 0,05)$; \#4- відмінності вірогідні порівняно з респондентами, що купують одяг для дітей віком від 11 до 14 років $(\leq 0,05) ; \#^{5}$ - відмінності вірогідні порівняно $з$ респондентами, що купують одяг для дітей віком від 15 до 17років $(\leq 0,05)$. 
років, на перше рангове місце ставлять якість одягу $(97,73 \%)$, на друге - зовнішній вигляд моделі $(86,36 \%)$, на третє - безпеку для здоров'я $(81,80 \%)$. Уподобаннями дитини насамперед переймаються споживачі $(96,67 \%)$, які мають дітей від 15 до 17 років. Для цієї категорії покупців також важливі такі фактори, як якість одягу та зовнішній вигляд моделі $(94,74 \%$ 93,33\%).

Як відомо, різні складов

ний із Китаю, вірогідно частіше порівняно з відсотком батьків дітей меншого віку $(p \leq 0,05)$.

Незаперечно, що головним фізіолого-гігієнічним призначенням натільної білизни (перший шар пакета одягу) $€$ поглинання поту та інших виділень шкіри, сприяння гарній вентиляції простору між шкірою першим шаром одягу. Тому тканини, що їх використовують для натільної білизни, повинні насамперед мати високу гігроскопічність, гарну повітряпроникливість, бути гідрофільними. Найбільше цим вимогам відповідають натуральні тканини. Зважаючи на це, проводилося опитування батьків щодо їхнього ставлення до наявності синтетичних волокон у складі тканин, що використовуються для виготовлення дитячого одягу першого шару. Опитування показало, що від $80,65 \%$ до $100,00 \%$ батьків дітей віком $1-14$ років і $56,67 \%$ батьків дітей віком 15-17 років мають негативне ставлення до наявності синтетичних волокон у складі тканин для дитячого одягу першого шару.

Щодо факторів, які впливають на вибір дитячого одягу, то хоча основна кількість батьків пріоритетними вважають одні й ті саме фактори, тим не менш їхня вагомість у різних вікових групах різна (табл. 1).

Так, батьки дітей 1-3 років перше рангове місце віддають якості товару $(100,00 \%$ респондентів), друге - безпеці для здоров'я $(80,65 \%)$, трете складу тканини, з якої пошитий одяг $(74,19 \%)$. Для батьків дітей вікових груп 4-6 років та 11-14 років пріоритетність факторів у порядку зменшення розташовуються таким чином: зовнішній вигляд моделі $(97,37 \%$ і 94,60\% відповідно) якість $(94,74 \%$ і $89,19 \%)$ безпека для здоров'я $(86,85 \%$ i $89,19 \%)$. Респонденти, що мають дітей 7-10 функції. Нині до поняття пакета одягу входять такі основні складові: натільна білизна, панчішно-шкарпеткові вироби (1-й шар), сукні, блузи, сорочки, верхній трикотаж (2-й шар), вироби костюмного асортименту та верхній одяг (3-й шар).

Нами встановлено тривалість безпосереднього контакту дітей 1-17 років з різними складовими пакета одягу протягом доби (табл. 2).

Так, середня тривалість носіння одягу першого шару становить в осінньо-зимовий

Таблиця 2

Тривалість безперервного носіння окремих видів одягу протягом доби (години)

\begin{tabular}{|c|c|c|c|c|c|}
\hline \multirow{2}{*}{$\begin{array}{c}\text { Вид одягу та } \\
\text { період року }\end{array}$} & \multicolumn{5}{|c|}{ Тривалість безперервної носіння (годин на добу) } \\
\cline { 2 - 5 } & \multicolumn{5}{|c|}{ Вікова група дітей (роки) } \\
\cline { 2 - 5 } & $\begin{array}{c}1-3, \\
\mathrm{n}=31\end{array}$ & $\begin{array}{c}4-6, \\
\mathrm{n}=38\end{array}$ & $7-10, \mathrm{n}=44$ & $\begin{array}{c}11-14, \\
\mathrm{n}=37\end{array}$ & $\begin{array}{c}15-17, \\
\mathrm{n}=30\end{array}$ \\
\hline \multicolumn{5}{|c|}{ Одяг першого шару } \\
Панчішно-шкарпеткові вироби
\end{tabular}

\begin{tabular}{|c|c|c|c|c|c|}
\hline $\begin{array}{l}\text { осінньо-зимо- } \\
\text { вий період }\end{array}$ & $\begin{array}{c}10,45 \pm 0,89 \\
\# 2\end{array}$ & $\begin{array}{c}8,03 \pm 0,30 \\
\# 1,3,4,5\end{array}$ & $\begin{array}{c}9,86 \pm 0,32 \\
\# 2\end{array}$ & $\begin{array}{c}9,73 \pm 0,55 \\
\# 2\end{array}$ & $\begin{array}{c}9,60 \pm 0,32 \\
\# 2\end{array}$ \\
\hline $\begin{array}{l}\text { весняно-літній } \\
\text { період }\end{array}$ & $\begin{array}{c}6,13 \pm 0,45 \\
\star \# 2\end{array}$ & $\begin{array}{c}4,74 \pm 0,27 \\
\quad * 1,3,4\end{array}$ & $\begin{array}{c}6,70 \pm 0,3 \text { * } \\
\# 2\end{array}$ & $\begin{array}{c}6,27 \pm 0,3 \\
* \# 2\end{array}$ & $\underset{\star}{5,67 \pm 0,45}$ \\
\hline \multicolumn{6}{|c|}{ Натільна білизна } \\
\hline $\begin{array}{l}\text { осінньо-зимо- } \\
\text { вий період }\end{array}$ & $\begin{array}{c}11,35 \pm 0,8 \\
\text { o } 2,3 \# 2\end{array}$ & $\begin{array}{c}10,18 \pm 0,6 \\
\text { o } 2,3 \# 3\end{array}$ & $\begin{array}{c}12,75 \pm 0,7 \\
2 \circ 2,3 \# 2\end{array}$ & $\begin{array}{c}11,57 \pm 0,477 \\
\text { o } 2,3\end{array}$ & \begin{tabular}{|c|}
$10,93 \pm 0,64$ \\
o 2,3
\end{tabular} \\
\hline $\begin{array}{l}\text { весняно-літній } \\
\text { період }\end{array}$ & $\begin{array}{c}8,32 \pm 0,98 \\
\diamond\end{array}$ & $\begin{array}{c}6,92 \pm 0,38 \\
\diamond \# 3,4\end{array}$ & $\begin{array}{c}9,57 \pm 0,61 \\
\diamond \# 2\end{array}$ & $\begin{array}{c}8,78 \pm 0,47 \\
\diamond \# 2\end{array}$ & $\begin{array}{c}9,13 \pm 0,45 \\
\diamond\end{array}$ \\
\hline \multicolumn{6}{|c|}{ Одяг другого шару } \\
\hline $\begin{array}{l}\text { повсякденного } \\
\text { використання }\end{array}$ & $\begin{array}{c}7,39 \pm 0,80 \\
01,3\end{array}$ & $\begin{array}{c}7,16 \pm 0,34 \\
01,3 \# 4\end{array}$ & $\begin{array}{c}7,34 \pm 0,32 \\
01,3\end{array}$ & $\begin{array}{c}8,22 \pm 0,311 \\
\circ 3 \text { \#2 }\end{array}$ & $\begin{array}{c}8,00 \pm 0,41 \\
01,3\end{array}$ \\
\hline $\begin{array}{l}\text { епізодичного } \\
\text { використання }\end{array}$ & $\begin{array}{c}4,48 \pm 0,45 \\
\square\end{array}$ & $\begin{array}{c}3,89 \pm 0,34 \\
\square\end{array}$ & $\begin{array}{c}4,09 \pm 0,25 \\
\square\end{array}$ & $\begin{array}{c}4,49 \pm 0,31 \\
\square\end{array}$ & $\begin{array}{c}4,33 \pm 0,50 \\
\square\end{array}$ \\
\hline \multicolumn{6}{|c|}{ Одяг третього шару } \\
\hline $\begin{array}{l}\text { повсякденного } \\
\text { використання }\end{array}$ & $\begin{array}{c}4,68 \pm 0,31 \\
01,2 \# 4\end{array}$ & $\begin{array}{c}4,26 \pm 0,34 \\
01,2 \# 4\end{array}$ & $\begin{array}{c}4,36 \pm 0,32 \\
01,2 \# 4\end{array}$ & $\begin{array}{c}3,38 \pm 0,27 \\
01,2 \# 1,2,3,5\end{array}$ & \begin{tabular}{|c|}
$4,37 \pm 0,32$ \\
$01,2 \# 4$
\end{tabular} \\
\hline $\begin{array}{l}\text { епізодичного } \\
\text { використання }\end{array}$ & $\begin{array}{c}2,97 \pm 0,18 \\
\square \# 4\end{array}$ & $\begin{array}{c}2,97 \pm 0,30 \\
\square \# 4\end{array}$ & $\begin{array}{c}2,82 \pm 0,18 \\
\square \# 4\end{array}$ & $\begin{array}{c}1,95 \pm 0,12 \\
\square \# 1,2,3,5\end{array}$ & $\begin{array}{c}2,60 \pm 0,23 \\
\square \# 4\end{array}$ \\
\hline
\end{tabular}

Примітки: * - відмінності вірогідні порівняно з тривалістю безперервного носіння панчішно-шкарпеткових виробів в осінньозимовий період $(\leq 0,05) ; \diamond-$ відмінності вірогідні порівняно з тривалістю безперервного носіння натільної білизни в осінньозимовий період $(\leq 0,05)$; $\mathrm{O}^{1}$ - відмінності вірогідні порівняно 3 тривалістю безперервного носіння одягу першого шару $(\leq 0,05)$; $\mathrm{O}^{2}$ - відмінності вірогідні порівняно з тривалістю безперервного носіння одягу другого шару $(\leq 0,05) ;$ о3 $^{3}$ відмінності вірогідні порівняно з тривалістю безперервного носіння одягу третього шару (<0,05); $\square$ - відмінності вірогідні порівняно з тривалістю безперервного носіння одягу повсякденного використання $(\leq 0,05)$; \#1 - відмінності вірогідні порівняно з респондентами, що

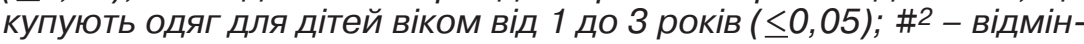
ності вірогідні порівняно з респондентами, що купують одяг для дітей віком від 4 до 6 років $(\leq 0,05) ;$ \#3 - відмінності вірогідні порівняно з респондентами, що купують одяг для дітей віком від

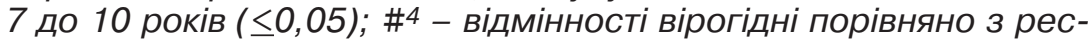
пондентами, що купують одяг для дітей віком від 11 до 14 років $(\leq 0,05)$; \#5 - відмінності вірогідні порівняно з респондентами, що купують одяг для дітей віком від 15 до 17років (<0,05). 
період $(10,45 \pm 2,89)$ годин на добу, а у весняно-літній - $(7,22$ $\pm 0,47)$. При цьому тривалість носіння одягу першого шару дітьми всіх вікових груп була вірогідно довшою (у середньому в 1,5 рази) порівняно з тривалістю носіння одягу другого шару (у середньому в 2,7 рази) та порівняно 3 тривалістю носіння одягу третього шару $(\leq 0,05)$. Також з'ясовано, що тривалість безперервного використання панчішно-шкарпеткових виробів і натільної білизни в осінньо-зимовий період у дітей усіх вікових груп, що досліджувалися, був вірогідно довшим порівняно з тривалістю носіння аналогічних виробів у весняно-літній період $(\leq 0,05)$. Одяг другого шару повсякденного використання діти носять від $(7,16 \pm 0,34)$ до $(8,22 \pm 0,31)$ годин на добу. При цьому тривалість носіння одягу епізодичного використання вірогідно коротша і складає від $(3,89 \pm 0,34)$ до $(4,49 \pm 0,31)$ годин на добу $(\leq 0,05)$. Повсякденним одягом третього шару діти користуються від $(3,38 \pm 0,27)$ до $(4,68 \pm 0,31)$ годин на добу, що становить вірогідно меншу тривалість, ніж носіння одягу другого шару $(\leq 0,05)$. Проте тривалість носіння одягу третього шару епізодичного використання вірогідно коротша і становить від $(1,95 \pm 0,12)$ до $(2,97 \pm 0,18)$ годин на добу $(\leq 0,05)$.

\section{Висновки}

1. Аналіз результатів анкетування свідчить про те, що понад дві третини опитаних батьків $(68,89 \pm 3,45) \%$ купують дитячий одяг більш ніж 4 рази на рік. Майже третина батьків $(28,89 \pm 3,38) \%$ купує одяг чотири рази на рік, а кожна двадцять п'ята родина - один раз на рік. 73,89\% батьків планують купівлю предметів одягу заздалегідь, а 70,56\% респондентів здійснюють її за участі дітей.

2. Переважна кількість батьків купує одяг у гіпермаркетах та магазинах, де є спеціалізовані відділи $(76,67 \pm 3,15) \%$. $41,67 \%$ родин купують одяг в Інтернет-магазинах, а (45,00 \pm $3,71) \%$ дітей носять одяг, придбаний у приватних осіб на ринку. 11,11\% респондентів виготовляють одяг самі.

3. Серед країн-виробників батьки віддають перевагу вітчизняним виробникам (70,00 \pm
3,42)\%, виробникам із Туреччини $(48,89 \pm 3,73) \%$, країн €C $(42,22 \pm 3,68) \%$ та Китаю $(30,00 \pm 3,42) \%$.

4. Опитування показало, що від 80,65\% до 100,00\% батьків дітей віком до 14 років і 56,67\% батьків дітей віком 15-17 років мають негативне ставлення до наявності синтетичних волокон у складі тканин для дитячого одягу першого шару.

5. Провідними факторами, що впливають на вибір одягу при його купівлі, батьки зазначили якість $(95,00 \pm$ $1,62) \%$, зовнішній вигляд $(87,22 \pm 2,49) \%$, безпеку для здоров'я $(81,67 \pm 2,88) \%$, склад тканини $(75,00 \pm 3,23) \%$, ціну $(59,44 \pm 3,66) \%$, уподобання дитини $(57,78 \pm 3,68) \%$ та торговельну марку або фірмувиробника $(51,67 \pm 3,72) \%$.

6. Середня тривалість носіння одягу першого шару становить в осінньо-зимовий період $(10,45 \pm 2,89)$ годин на добу, а у весняно-літній - $(7,22 \pm 0,47)$. При цьому тривалість носіння одягу першого шару дітьми усіх вікових груп вірогідно довша (у середньому в 1,5 рази) порівняно 3 тривалістю носіння одягу другого шару (у середньому у 2,7 рази) та порівняно з тривалістю носіння одягу третього шару $(\leq 0,05)$.

ЛІТЕРАТУРА

1. Зрезарцев М.П.

Зрезарцев В.М., Параніч В.П. Товарознавство сировини та матеріалів : навч. посібник. К. : Центр учбової літератури, 2008. 404 c.

2. Войнаш Л.Г., Байдакова Л.І., Діаніч М.М., Козьмич Д.І. Товарознавство непродовольчих товарів. Ч. 2. К. : НМЦ «Укоопосвіта», 2004. $532 \mathrm{c}$.

3. Патлашенко О.А.

Матеріалознавство швейного виробництва. Навчальний посібник. Київ : Арістей, 2007. $288 \mathrm{c}$.

4. Про забезпечення санітарного та епідемічного благополуччя населення : Закон України від 24.02.1994 р. № 4004-XII. Режим доступу: http://zakon4.rada.gov.ua/laws/ show/4004-12.

5. Доскин В.А., Келлер Х. Мураненко Н.М., ТонковаЯмпольская Р.В.

Морфофункциональные константы детского организма : справочник. М. : Медицина, 1997. 288 c.
6. Антомонов М.Ю.

Математическая обработка и анализ медико-биологических данных. К., 2006. 558 с.

REFERENCES

1. Zrezartsev M.P., Zrezartsev V.M. and Paranich V.P. Tovaroznavstvo syrovyny ta materialiv : navchalnyi posibnyk [Commodity Science of Stock and Materials: Manual]. Kyiv ; 2008 : 404 p. (in Ukrainian).

2. Voinash L.G., Baidakova L.I., Dianich M.M. and Kozmich D.I. Tovaroznavstvo neprodovolchykh tovariv. Chastyna 2 [Commodity Science of Nonfood Goods. Part 2]. Kyiv ; 2004 : 532 p. (in Ukrainian).

3. Patlashenko O.A.

Materialoznavstvo shveinoho vyrobnytstva. Navchalnyi posibnyk [Materials Science of Sewing Production. Manual]. Kyiv : Aristei ; 2007 : 288 p. (in Ukrainian).

4. Pro zabezpechennia sanitarnoho ta epidemichnoho blahopoluchchia naselennia : Zakon Ukrainy vid 24 liutoho 1994 roku, № 4004-XII [On the Provision of Sanitary and Epidemiological Well-Being of the Population : Law of Ukraine, February 24, 1994, № 4004-XII]. Available at : http://zakon4.rada.gov.ua/laws/ show/4004-12

(in Ukrainian).

5. Doskin V.A., Keller Kh.,

Muranenko N.M. and TonkovaYampolskaia R.V. Morfofunktsionalnye konstanty detskogo organizma : spravochnik [Morphofunctional Constants of Child's Organism : Reference

Book]. Moscow : Meditsina ; 1997 : 288 p.

(in Russian).

6. Antomonov M.Yu.

Matematicheskaia obrabotka i analiz medico-biologicheskikh dannykh [Mathematical Processing and Analysis of Medico-Biological Data]. Kiev; 2006 : 558 p. (in Russian).

Надійшла до редакції 17.08.2017 